\title{
Crohn's disease and cheilitis
}

\author{
Abdulrahman A Al-Hussaini MD MRCPUK, Helen M Machida MD FRCPC, J Decker Butzner MD FRCPC
}

\begin{abstract}
AA Al-Hussaini, HM Machida, JD Butzner. Crohn's disease and cheilitis. Can J Gastroenterol 2003;17(7):445-447.

A five-year-old boy presented to his family physician with painless swelling of both lips. One year later he developed abdominal pain, nonbloody diarrhea, weight loss and joint pains. Colonoscopic examination demonstrated patchy erythema, friability and multiple aphthous ulcers consistent with the appearance of Crohn's colitis, and treatment with prednisone was initiated. Colonic biopsies displayed a chronic inflammatory cell infiltrate, focal cryptitis and fissure formation. The patient's lip swelling relapsed on multiple occasions when steroids were tapered, despite minimal intestinal symptoms of Crohn's disease. The objective of the present report is to alert physicians to this unusual presentation of Crohn's disease and that cheilitis may run a protracted course.
\end{abstract}

Key Words: Cheilitis; Crohn's disease; Lip lesions

\section{Maladie de Crohn et chéilite}

Des parents ont consulté leur médecin de famille pour l'enflure indolore des lèvres de la bouche de leur fils de cinq ans. Un an plus tard, l'enfant a commencé à présenter des douleurs abdominales, de la diarrhée non sanglante, une perte de poids et de l'arthralgie. L'examen du côlon a révélé des zones friables, érythémateuses et de nombreux ulcères aphteux, signes compatibles avec la maladie de Crohn; un traitement à la prednisone a donc été amorcé. Les biopsies du côlon ont montré la présence d'un infiltrat cellulaire inflammatoire chronique, une cryptite en foyer et la formation de fissures. L'enflure des lèvres est réapparue plusieurs fois durant la réduction progressive des doses de stéroïdes, et ce, malgré des symptômes intestinaux très peu marqués de la maladie de Crohn. Le présent article vise à attirer l'attention des médecins sur ce tableau inhabituel de la maladie de Crohn et sur le fait que la chéilite peut se prolonger.
$\mathrm{O}_{\mathrm{d}}^{\mathrm{r}}$ al lesions are not uncommon clinical findings in Crohn's disease, and may occur before the onset of gastrointestinal symptoms or during the disease course (1-14). Crohn's disease presenting as cheilitis in young children is rare. Just as with bowel disease, oral lesions run a chronic course with periods of quiescence interrupted by flare-ups. These lesions may cause psychological distress and significant morbidity, such as pain and difficulty with eating as well as phonation. We describe a child with cheilitis antedating the intestinal symptoms of Crohn's disease and a review of the literature with focus on the clinical characteristics and treatment of oral Crohn's disease.

\section{CASE PRESENTATION}

A five-year-old boy presented to his family physician with painless swelling of both lips. One year later, he developed abdominal pain, nonbloody diarrhea, weight loss and joint pains. His physical examination was notable for marked, diffuse, firm and nontender enlargement of both lips, more pronounced in the lower lip, with focal superficial ulcers (Figure 1). The remainder of the oral mucosa appeared to be normal. Bacterial, fungal and viral cultures of the lip lesions were repeatedly negative. Colonoscopic examination demonstrated noncontiguous erythema, edema, friability and aphthous ulcers throughout the colon with a normal-appearing terminal ileum. Mucosal biopsies showed chronic inflammatory cell infiltrate, focal cryptitis, distortion of crypt architecture and fissure formation (Figure 2). Upper gastrointestinal endoscopy with mucosal biopsies and an upper gastrointestinal series with fol- low-through were normal. The patient was diagnosed with Crohn's colitis, and was treated with oral prednisone $(2 \mathrm{mg} / \mathrm{kg} /$ day $)$ and mesalamine $(50 \mathrm{mg} / \mathrm{kg} /$ day $)$. Over a period of 24 months, when steroids were tapered or discontinued, his condition relapsed on multiple occasions with nonpruritic and painless swelling of both lips, accompanied by minimal intestinal symptoms. Steroid dependency led to a three-month trial of enteral feeding and daily azathioprine $(2 \mathrm{mg} / \mathrm{kg} /$ day $)$. The cheilitis improved but did not resolve. Three months after the discontinuation of enteral feeding, the cheilitis worsened with no accompanying intestinal symptoms. Repeat colonoscopic examination and mucosal biopsies demonstrated no evidence of active colitis. A biopsy specimen of the lower lip showed a diffuse infiltrate of lymphocytes, plasma cells and mast cells (Figure 3). No acid-fast bacilli or fungal elements were observed. Immunostaining and culture for herpes simplex virus were negative. Other investigations revealed normal $\mathrm{C} 1$-esterase inhibitor, $\mathrm{C} 3, \mathrm{C} 4$ and $\mathrm{CH} 50$, and a negative nitroblue tetrazolium test. With the introduction of oral metronidazole $250 \mathrm{mg}$ twice a day, the child's cheilitis improved, allowing the reduction of the prednisone dose to $5 \mathrm{mg}$ every second day.

\section{DISCUSSION}

The differential diagnosis of cheilitis includes hereditary angioedema, recurrent erysipelas, contact dermatitis, hematoma, dentoalveolar abscess, hemangioma, lymphangioma, neurofibroma, sarcoidosis, Anderson-Fabry disease,

Department of Pediatrics, Alberta Children's Hospital, Calgary, Alberta

Correspondence: Dr Decker Butzner, Department of Pediatrics, Alberta Children's Hospital, 1820 Richmond Road South West, Calgary, Alberta

T2T 5C7. Telephone 403-943-7721, fax 403-943-7321, e-mail butzner@ucalgary.ca

Received for publication November 8, 2002. Accepted February 12, 2003 


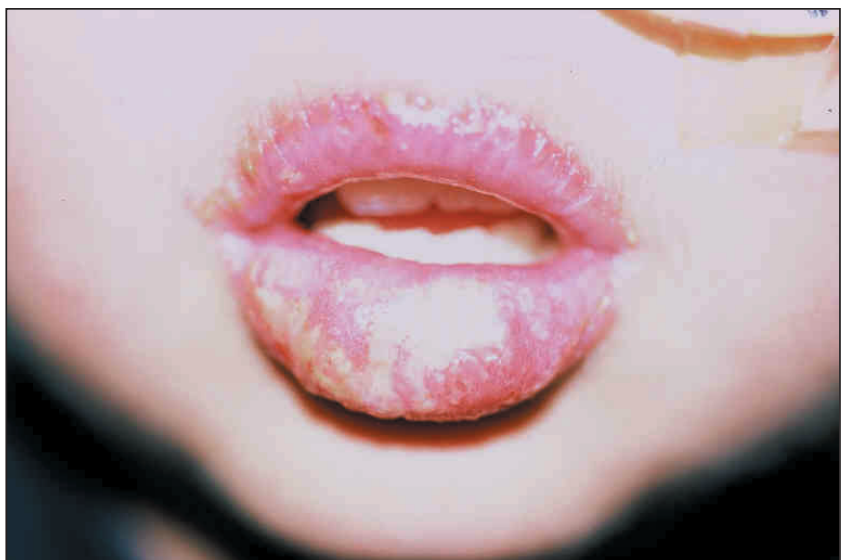

Figure 1) Lip swelling in Crohn's cheilitis

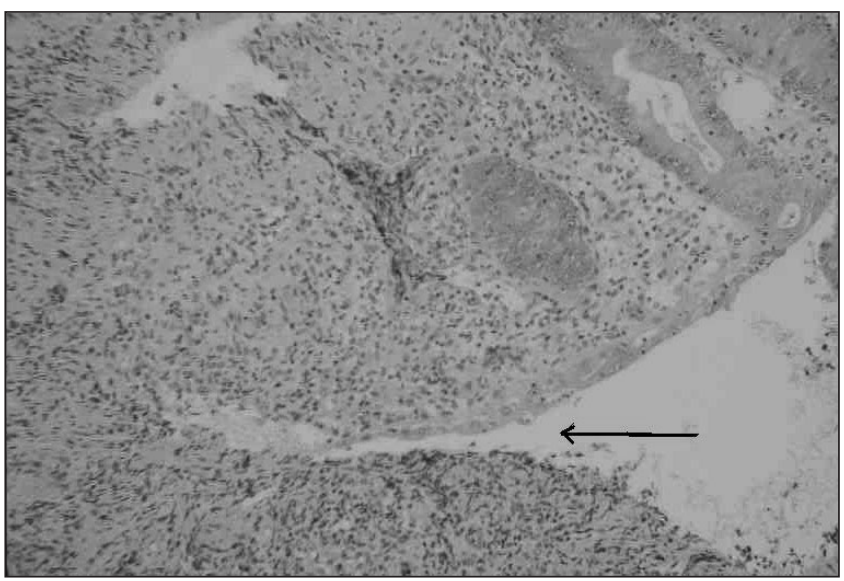

Figure 2) Colonic mucosal biopsy showing chronic inflammatory cell infiltrate, cryptitis, distortion of crypts and fissure formation (arrow)

leukemic infiltrate, granulomatous infection, MelkerssonRosenthal syndrome or Crohn's disease (15). Oral lesions in Crohn's disease are reported to occur in 5\% to $20 \%$ of patients $(1,2)$. An incidence of up to $48 \%$ was reported on oral examination of 45 children with newly diagnosed Crohn's disease (3). Three studies demonstrated oral lesions to be more frequent in patients with colonic disease $(4,5)$ or perianal disease $(6)$ than that confined to the small intestine. No obvious predilection could be established in other studies $(3,7)$.

Crohn's disease that presents with cheilitis one year before the onset of intestinal symptoms is rarely reported in the literature. The youngest child reported was a three-year-old boy who had granulomatous cheilitis and Crohn's disease (8). In nine of 29 patients, oral and/or facial lesions presented at least four years before the diagnosis of Crohn's disease (9). The oral lesions generally develop when bowel disease is active (10-12). An interesting feature in our patient was the persistence of lip swelling after he went into clinical remission of the intestinal symptoms. Others have demonstrated that patients with active Crohn's disease did not have a higher frequency of oral lesions than patients with quiescent disease (13).

The most common sites of oral involvement in order of frequency are lips, gingival mucosa, buccal mucosa and the palate (7). Aphthous stomatitis is a frequent finding in patients with Crohn's disease. However, oral ulcers occur in as many as $20 \%$

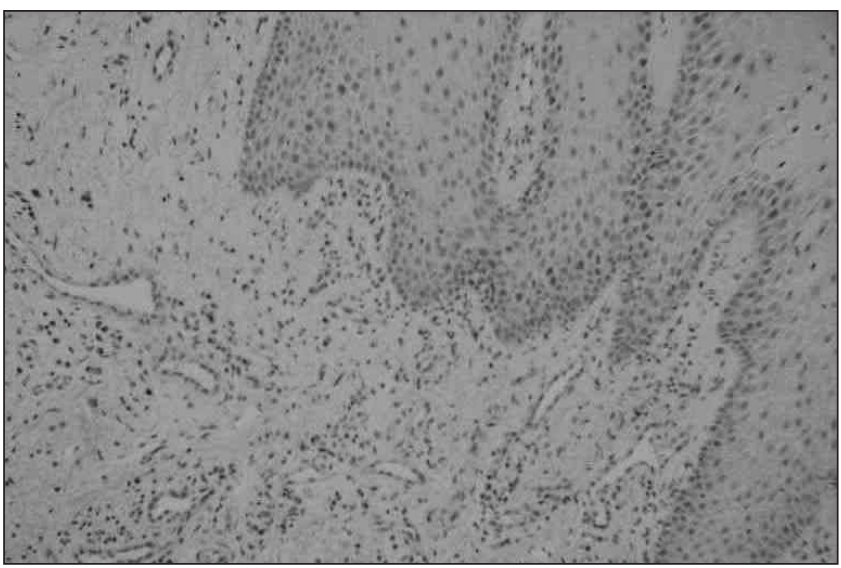

Figure 3) Lip biopsy showing diffuse infiltrate of lymphocytes, plasma cells and mast cells

of the general population and $5 \%$ of ulcerative colitis patients $(11,14)$. Therefore, the clinical and diagnostic relevance of simple aphthous ulcers in a patient with suspected Crohn's disease is uncertain. Conversely, a number of other oral lesions, though less common, are considered to be disease-specific in patients with Crohn's disease. These include lip swelling and fissure, buccal mucosal swelling and cobblestoning, deep linear ulceration, mucosal tags and localized gingivostomatitis $(3,7,9)$. Deep linear ulcerations were almost always painful and associated with difficulty in chewing and swallowing, while lip swellings were cosmetically disfiguring but usually not painful (9).

At both the macroscopic and microscopic level, the oral lesions in Crohn's disease are similar to the findings in the intestine. Biopsies of these lesions have frequently shown noncaseating granuloma, ulceration, fissuring, diffuse or focal lymphocyte, plasma cell and histiocytic infiltrate of the lamina propria and submucosa with edema (16). Granuloma detection rates in oral biopsies and intestinal biopsies from patients with oral Crohn's disease ranged from $45 \%$ to $71 \%$ and from $68 \%$ to $78 \%$, respectively (7). This rate is much higher than that of granuloma detected in the intestinal biopsies of Crohn's disease patients without oral lesions. The biopsy specimen of the lip of our patient was compatible with but not diagnostic of Crohn's disease.

Treatment is challenging for these patients because remission of the gastrointestinal symptoms may not translate into resolution of oral lesions. If oral lesions are painful or facially disfiguring, then a specific therapy is indicated. Cheilitis, one of the more severe oral lesions, shows a variable response to treatment. Treatment options reported to be efficacious include metronidazole, clofazimine, steroids, azathioprine, thalidomide, topical tacrolimus and infliximab (7,17-23). Our patient's cheilitis improved on metronidazole, which has been reported to be effective in the treatment of recalcitrant Crohn's cheilitis (17). Systemic steroids, with or without azathioprine, induced remission in about $50 \%$ of patients, and topical or intralesional steroids induced remission in $58 \%$ of patients (7). Thalidomide has been beneficial in refractory oral Crohn's disease, but appears to require long term therapy $(19,20)$. Topical tacrolimus induced remission in three patients with treatment-resistant oral Crohn's disease with no evidence of significant systemic absorption (21). Subsequently, significant systemic absorption has been reported during topical tacrolimus therapy for orofacial Crohn's disease (22). This was 
associated with the recurrence of a varicella zoster infection in the form of shingles. Mahadevan and Sandborn (23) recently described the first successful treatment of steroid-resistant orofacial Crohn's disease with infliximab.

The development of refactory cheilitis in children should alert physicians to the possibility of the diagnosis of Crohn's disease. Cheilitis may be characterized by a protracted course that is more resistant to treatment than intestinal Crohn's disease.

\section{REFERENCES}

1. Burgdorf W. Cutaneous manifestations of Crohn disease. J Am Acad Dermatol 1981;5:689-95.

2. Ploysangam T, Heubi J, Eisen D, et al. Cutaneous Crohn's disease in children. J Am Acad Dermatol 1997;36:697-704.

3. Pittock S, Drumm B, Fleming P, et al. The oral cavity in Crohn's disease. J Pediatr 2001;138:767-71.

4. Basu MK, Asquith P. Oral manifestations of inflammatory bowel disease. J Clin Gastroenterol 1980;9:307-21.

5. Greenstein AJ, Janowitz HD, Sachar DB. The extra-intestinal complications of Crohn's disease and ulcerative colitis: A study of 700 patients. Medicine (Baltimore) 1976;55:401-12.

6. Dupuy A, Cosnes J, Revuz J, Delchier J-C, Gendre JP, Cosnes A. Oral Crohn disease: Clinical characteristics and long-term follow-up of 9 cases. Arch Dermatol 1999;135:439-42.

7. Plauth M, Jenss H, Meyle J. Oral manifestation of Crohn's disease: An analysis of 79 cases. J Clin Gastroenterol 1991;13:29-37.

8. Dummer W, Lurz C, Jeschke R, Meissner N, Rose C, Brocker EB. Granulomatous cheilitis and Crohn's disease in a 3-year-old boy. Pediatr Dermatol 1999;16:39-42.

9. Williams AJ, Wray D, Ferguson A. The clinical entity of orofacial Crohn's disease. Q J Med 1991;79:451-8.

10. Basu MK. Oral manifestations of Crohn's disease: studies in the pathogenesis. Proc R Soc Med 1976;69:765-6.
11. Hyams JS. Extraintestinal manifestations of inflammatory bowel disease in children. J Pediatr Gastroenterol Nutr 1994;19:7-17.

12. Halme L, Meurman JH, Laine P, et al. Oral findings in patients with active or inactive Crohn's disease. Oral Surg Oral Med Oral Pathol 1993;76:175-81.

13. Lisciandrano D, Ranzi T, Carrassi A, et al. Prevalence of oral lesions in inflammatory bowel disease. Am J Gastroenterol 1996;91:7-10.

14. Talbot T, Jewell L, Schloss E, Yakimets W, Thomson A. Cheilitis antedating Crohn's disease: Case report and literature update of oral lesions. J Clin Gastroenterol 1984;6:349-54.

15. Somech R, Harel A, Rotshtein M, Brazowski E, Reif S. Granulomatosis cheilitis and Crohn disease. J Pediatr Gastroenterol Nutr 2001;32:339-41.

16. Clayton R, Feiwel M. Crohn's disease of the mouth. Proc R Soc Med 1975;68:650-1.

17. Kano Y, Shiohara T, Yagita A, Nagashima M. Treatment of recalcitrant cheilitis granulomatosa with metronidazole. J Am Acad Dermatol 1992;4:629-30.

18. Podmore P, Burrows D. Clofazimine - An effective treatment for Melkersson-Rosenthal syndrome or Miescher's cheilitis. Clin Exp Dermatol 1986;2:173-8.

19. Odeka EB, Miller V. Thalidomide in oral Crohn's disease refractory to conventional medical treatment. J Pediatr Gastroenterol Nutr 1997;25:250-1.

20. Weinstein TA, Sciubba JJ, Levine J. Thalidomide for the treatment of oral aphthous ulcers in Crohn's disease. J Pediatr Gastroenterol Nutr 1999;28:214-6.

21. Casson DH, Eltumi M, Tomlin S, Walker-Smith JA, Murch SH. Topical tacrolimus may be effective in the treatment of oral and perineal Crohn's disease. Gut 2000;47:436-40.

22. Russell RK, Richardson N, Wilson DC. Systemic absorption with complications during topical tacrolimus treatment for orofacial Crohn disease. J Pediatr Gastroenterol Nutr 2001;32:207-8.

23. Mahadevan U, Sandborn W. Infliximab for the treatment of orofacial Crohn's disease. Inflam Bowel Dis 2001;7:38-42. 


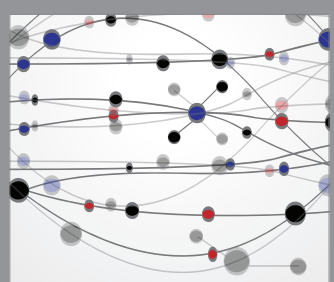

The Scientific World Journal
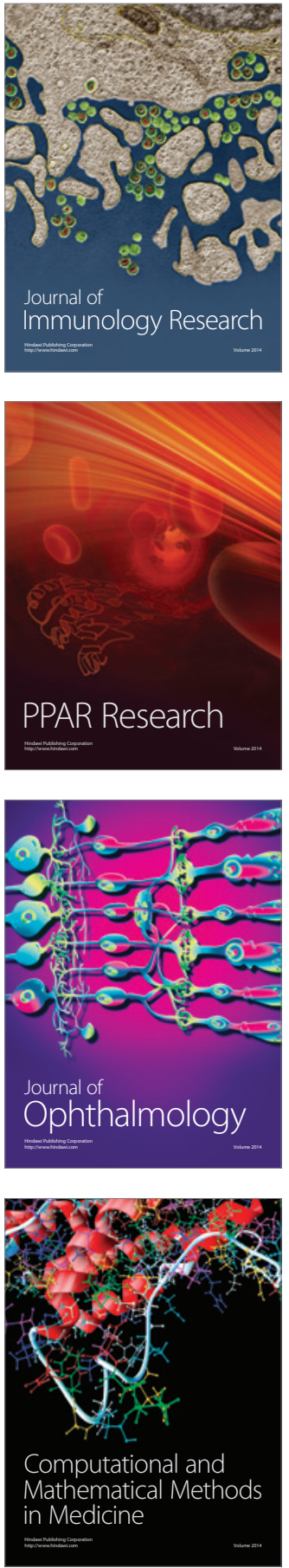

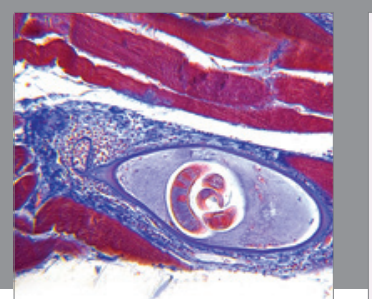

Gastroenterology Research and Practice

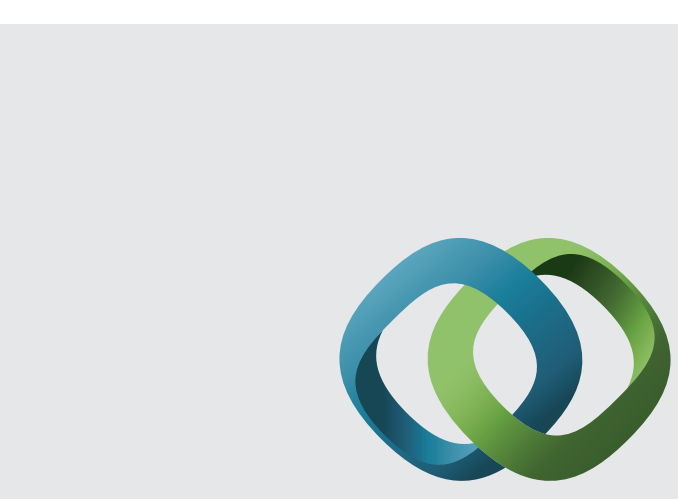

\section{Hindawi}

Submit your manuscripts at

http://www.hindawi.com
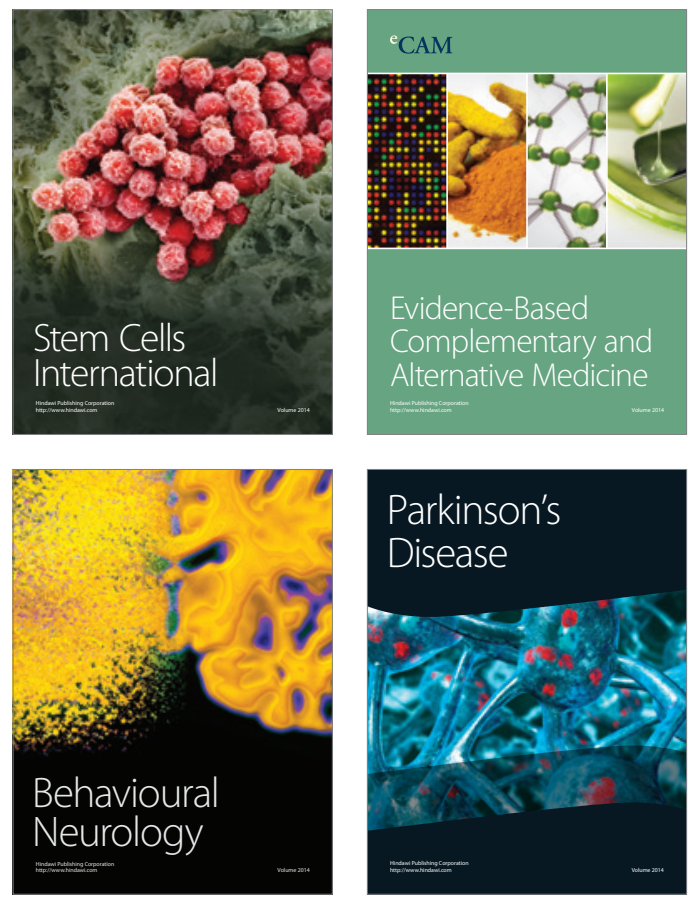
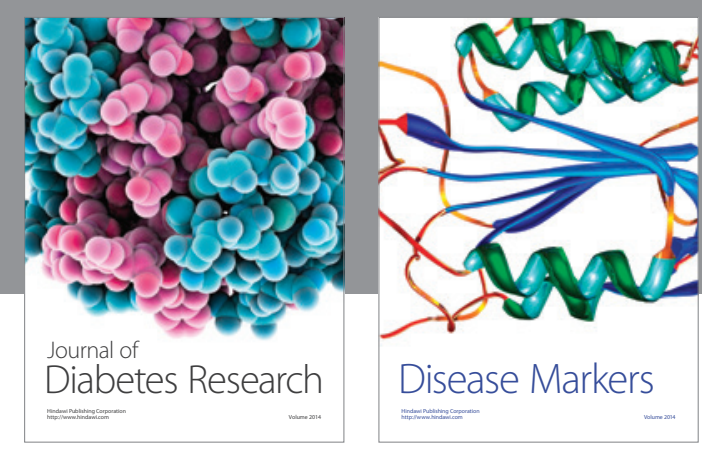

Disease Markers
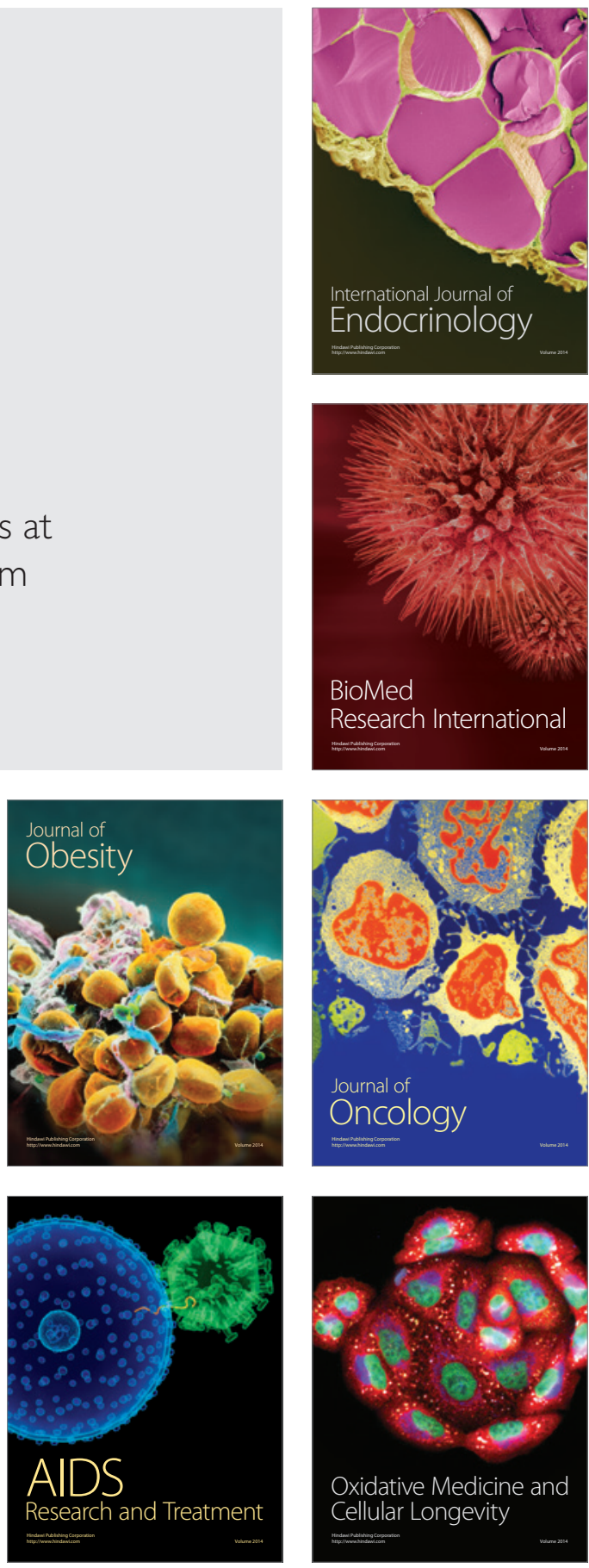